\title{
COMMUNITY BASED TOURISM DESTINATION ATTACHMENT AND RE-VISIT INTENTION: EFFECT OF ANTHROPOGENIC AND HEDONIC VALUE
}

\author{
Teck-Weng Jee ${ }^{1}$ \\ Hui Bun Ting \\ Mung Ling Voon
}

\begin{abstract}
This study attempts to determine tourists' re-visit intention towards community based tourism destinations in the context of a developing country. Tourists' anthropogenic value, hedonic value and destination attachment are investigated to determine what contributes to tourists' re-visit intention. In this study, a causal research design was adopted, and employed descriptive and Partial Least Squares-Structural Equation Modelling (PLSSEM). This study surveyed 216 tourists from different community-based tourism destinations in Sarawak, Malaysia. Findings of this study provide partial supports towards the effect of anthropogenic value and hedonic value on tourists' re-visit intention towards community-based tourism destinations, mediated by destination attachment. The study suggests to practitioners that it is crucial to understand the impact of tourists' anthropogenic value and hedonic value, as well as destination attachment and re-visit intention, especially, in developing effective marketing strategies for better market segmentation and targeting. Thus, the outcome of this study will help to expand the current knowledge on similar areas of community based tourism destinations, and contributively effect of anthropogenic value, hedonic value and destination attachment on re-visit intention towards community-based tourism destination in a developing country context.
\end{abstract}

Key words: Anthropogenic value, hedonic value, destination attachment, re-visit intention, community based tourism destination

\section{INTRODUCTION}

Globally, tourist arrival numbers continue to grow, and Southeast Asia have captured a large portion of the growth (Cochrane, 2007; Ly \& Bauer, 2017; Winter, 2007), which is being recognized through the sector's significant contribution to GDP (UNWTO, 2014). In Malaysia, the tourism sector is expected to contribute USD24.2 billion to GDP by 2027. In fact Malaysia ranks tourism as one of its most important industry sectors, after manufacturing and agriculture (Bhuiyan, Siwar, Ismail, Islam, \& Ehsan, 2011). The sector comprises a varied range of travel and tourism products and services, and one of these sub categories is community-based tourism (Chin \& Lo, 2017).

\footnotetext{
${ }^{1}$ Dr., Swinburne University of Technology, Sarawak Campus; tjee@ swinburne.edu.my;
} 
For developing countries, like Malaysia, extant tourism literature has identified revisit intention as a contributing factor to tourism spending (Promsivapallop \& Kannaovakun, 2017) and tourists' experience and satisfaction (Cole \& Chancellor, 2009). Also, past studies have identified perceived value as an indicator of re-visit intention, and have examined the potential mediating and moderating effect of destination attachment on re-visit intention in the context of community-based tourism destinations (Ramkissoon, Uysal, \& Brown, 2011). However, one challenge in Malaysia's tourism industry is that some destinations are not considered acceptable elements of the country's tourism brand. Therefore, this study assesses whether different perceived values (anthropogenic and hedonic value) towards community-based tourism destinations have an effect on re-visit intention, and whether there is a mediating role for destination attachment between destination images and re-visit intention. The rest of the paper discusses the relevant literature, the study methods, analysis and findings. Finally, the findings inform the study conclusion and implications.

\section{LITERATURE REVIEW}

\section{COMMUNITY-BASED TOURISM}

Community-based tourism (CBT) are related to local community involvement in sustainable tourism planning and development (Dodds, Ali, \& Galaski, 2018). Such CBT is based on the active participation of the local community (López-Guzmán, Sánchez-Cañizares, \& Pavón, 2011). Aside enhancing the relationship between the locals and the tourists, it also brings in the creation of community events which favor to this community-based tourism events and activities. The augmentation of the local community and the tourists through trading and job employment had aid in the growth of the economy, particularly in the tourism sector (Ibrahim \& Shuib, 2016). CBT is based on the creation of tourist products characterized by community participation in their development (Russell, 2000). Therefore, CBT aims to create a sustainable tourism in a direct and indirect way through proper tourism planning and development and involvement of the locals (Salazar, 2012).

The implementation of CBT had been seen in some developing countries, often in the context development for the aboriginal people, provision of wildlife management and protection of environment (Zeppel, 2006). CBT usually includes cultural exchange between the local community and the tourist on their daily activities. Several studies concluded on the benefits of CBT, such as provision of 
employment opportunities to the locals (Salazar, 2012), greater environmental awareness and provision of quality experiences (Lepp, 2007) as well as reduction on poverty at the destination community (Manyara \& Jones, 2007). In this regards the study stressed for a more sustainable community-based tourism which could benefit the local community and improving the growth of nation's economy.

\section{PERCEIVED VALUES}

To study consumer behavior, it is necessary to understand how consumers perceive value. Generally defined as consumers' overall judgment of the utility of a product or received service (Zeithaml, 1988), perceived value is clearly a subjective and potentially complex concept. Porter (1990) proposed that consumers perceived relative quality, service levels and complementary products or services as part of the value concept. In the tourism section, a heritage site study by Taylor and Shanka (2008) concluded that visitor perceived value was closely associated with the core heritage legacy of the historic property and the interpretation and explanation of the site's history. This inferred that tourism products have a primary or subsidiary element of enjoyment, which influences the perceived value of the customer. For a young visitor to the Balearics, enjoyment may be the primary consideration; but for a business traveller in Northern Europe, more utilitarian factors may be a priority with enjoyment lesser so. A wide body of literature on consumer value perceptions has acknowledged the hedonic, utilitarian dimensions of consumption (Holbrook, 1994, 2006). Several authors have applied these concepts to tourism. For example, Lim and Ang (2008) identified cross-cultural differences in perception of and response to utilitarian and hedonic promotions. These differences implied that the results from a relatively homogeneous audience, such as sampled for this research, may not easily translate across cultures. Furthermore, Ryu, Han, and Jang (2010) assessed the relationships of hedonic and utilitarian values and behavior. They considered the impact of instance repeat visits, recommendations and enjoyment ratings in the fast-casual restaurant industry, and concluded that hedonic and utilitarian values significantly influenced customer satisfaction and that satisfaction significantly influenced consumer behavior. Additionally, based on a study at an archaeological site, Martin-Ruiz, Castellanos-Verdugo, and Oviedo-Garcia (2010) noted that visitors' assessment of the archaeological site included service experience rather than service quality as a major contributor to value. Some major factors were identified as 'effort sacrifices', such as comfort during the visit (seating and rest areas), whereas 'access sacrifices' (time, parking and entering) were less important.

This study assesses the perceived value of visits to heritage attractions, measured on two dimensions. Enjoyment is the affective and hedonistic aim and value for money 
the more objective consideration of service quality. Cost is measured by a construct consisting of social, emotional, functional and conditional responses. These dimensions are calibrated by the visitors, based on their understanding and knowledge of the historic and aesthetic corpus of the attraction. Inferred from this premise, positive evaluations of service that enhance the hedonistic ambition of a visitor will lead to recommendation and repeat visits. This is supported by Apostolakis and Jaffrey (2005) who proposed that heritage tourism is going through a transitional phase; from product-led development of heritage attractions that emphasize exhibits and education, to a more visitor-orientated development that emphasizes consumer preferences and quality of personal experience.

Few studies have illuminated the experiential quality of heritage tourism developments, reported Chen and Chen (2010). Other authors have identified the need to improve visitors' behavioral intentions in heritage contexts, suggesting that high quality, satisfying experiences underpin visitors perceptions of good value (Lee, Petrick, \& Crompton, 2007). In their study, Chen and Chen (2010) summarized four models of the relationships between quality, satisfaction, value and behavioral intentions. The first model, based on service value literature, highlighted value had a singular and direct effect upon favorable outcomes. The second model proposed that satisfaction was the primary predictor of outcome measures. The third, inter-related model, suggested that service quality influences behavioral intentions only through the mediation of value and satisfaction. The fourth model assumed all three variables directly lead to favorable behavioral intentions.

It is proposed in this paper that a visitor to a heritage attraction will have a twodimensional expectation of service experience, reflecting the findings from Fick and Brent Ritchie (1991) and Otto and Ritchie (1996). The first dimension is directly related to the hospitality received and the extent to which the property accommodates personal and social needs for welcome, warmth and the utilitarian needs for comfort and efficiency. These are the 'anthropogenic' dimensions of service that cannot create enjoyment but which impede the hedonic aims of the visitor if absent. Otto and Ritchie (1996) regarded these as objective measures. The second dimension is the experiential, hedonic dimension. It is underpinned by service-dominant logic, where service engages with a visitor's current understanding of the historic and aesthetic core of the heritage attraction, providing stimulation, fascination and pleasure, Otto and Ritchie identified these as subjective, holistic/gestalt evaluations that have the capacity to create value in the experience. For instance, a visitor to a heritage site arrives with her or her knowledge and understanding of the property, largely taken from derived understanding, which may include formal education, legends, literary sources, and film. The attraction needs to 
meet these expectations through interactive on-site media or the site's staff (Chan \& Baum, 2007) to ensure visitor enjoyment. Furthermore, the conservation aims of the attraction and its heritage authenticity are successful, from a visitors' perspective, if they do not clash with their 'understanding' of it.

Anthropogenic and hedonic dimensions are evolving concepts in heritage experiences (Calver \& Page, 2013). However, their development has been predicated on the basis that visitors could only enjoy their experience if they were equipped with a formal knowledge of the humanities. While this requirement is now largely discounted, the role of visitor knowledge and understanding remains a topic of some contention.

\section{DESTINATION ATTACHMENT AND RE-VISIT INTENTION}

Destination attachment is formed between people and buildings, environments, homes, objects, landscapes, neighborhoods, towns, and cities (Cresswell, 2015). In the domain of tourism, destination attachment is defined as "the strength of the cognitive, emotional, functional and autobiographical bonds connecting the tourist with a destination" (Yuksel, Yuksel, \& Bilim, 2010). These components of destination attachment comprises destination dependency as functional attachment, destination identity which is also treated as tourist identity in relation to the destination development, affective bond refers as positive emotion, and automatic prominence that is positivity of thoughts and feelings for a destination (Veasna, Wu, \& Huang, 2013).

On the other side, re-visit intention is the readiness of an individual to make a visit to the same destination in future in order to purchase a vacation package (Stylos, Bellou, Andronikidis, \& Vassiliadis, 2017). The greater impression of a tourism destination and its associated attributes plays an important role to be formed an individual's intention to re-visit towards a particular destination (Song, Kim, \& Yim, 2017). Moreover Zhang, Fu, Cai and Lu (2014) argued that repeat visitation is considered to the most destination marketing organizations as a cost-effective and desirable market segment. Thus, destination marketers should consider the antecedents of a destination that influence re-visit intention of tourists towards community-based tourism destinations for successful tourism development.

Previous studies proposed that destination attachment connects both the tourists' cognitive and affective engagement with tourism activities at a particular destination (Huang, Qu, \& Cao, 2016). It is formed as a sign of affective attachment to those places through the process on which individuals form affective connections to these places (Yuksel et al., 2010), and affective connections comprised through positive, 
or negative or mixed feelings of tourists about a destination (Veasna et al., 2013), which in turn create re-visit intention towards a particular tourism destination. Past studies in this line constantly argued that destination attachment influence visitors to be repeatedly visits the same destination.

\section{CONCEPTUAL FRAMEWORK}

The conceptual framework of this study is built on extant of destination attachment and re-visits intention. This study proposes that perceived value (anthropogenic and hedonic) may or may not affect destination attachment and re-visit intention towards community-based tourism destinations. Destination attachment is also proposed as the mediating construct between perceived value (anthropogenic and hedonic) and re-visits intention towards community-based tourism destinations. The relational paths are illustrated in a conceptual framework for destination attachment and revisit intention towards various local community tourism destinations in the context of Malaysia.

In particular, the framework contended that the proposed two antecedents (e.g. anthropogenic and hedonic value) of perceived value affect both destination attachment and re-visit intention. This proposition received support from the studies in similar areas (Huang et al., 2016). Perceived value is an influential antecedent of destination attachment (Iso-Ahola, 1982; Nghiêm-Phú, 2018), and destination attachment has a significant influence on re-visit intention (Waheed \& Hassan, 2016). However, as presented in Figure-1, it can be anticipated that perceived value (anthropogenic and hedonic) have direct impact on destination attachment and revisit intention. Therefore, it is expected that the strong perceived value of a destination positively influences to the destination attachment.

The framework also revealed that destination attachment is suggested to mediate the relationship between perceived value (anthropogenic and hedonic) and re-visit intention (Suntikul \& Jachna, 2016). The rationale behind such a relationship can be explained through the lenses of place attachment which is predicted by the activity involved and place characteristics (Hosany, Prayag, Van Der Veen, Huang, \& Deesilatham, 2017). In particular, sense of belonging and being identified with a place contributes to attachment that could clearly promote re-visit intention (Wickham, 2000). The above discussions and arguments leads to the following hypotheses:

H1: Perceived value ([a] anthropogenic, and [b] hedonic) positively affect destination attachment towards community based tourism destination. 
$\mathrm{H}$ 2: Perceived value ([a] anthropogenic, and [b] hedonic) positively affect re-visit intention towards community based tourism destination.

H3: Destination attachment positively affects re-visits intention towards community based tourism destination.

H4: Perceived value ([a] anthropogenic, and [b] hedonic) positively affect re-visit intention, mediated by destination attachment towards community based tourism destination.

Figure 1: Perceived Value and Destination Attachment influence on Re-visit Intention

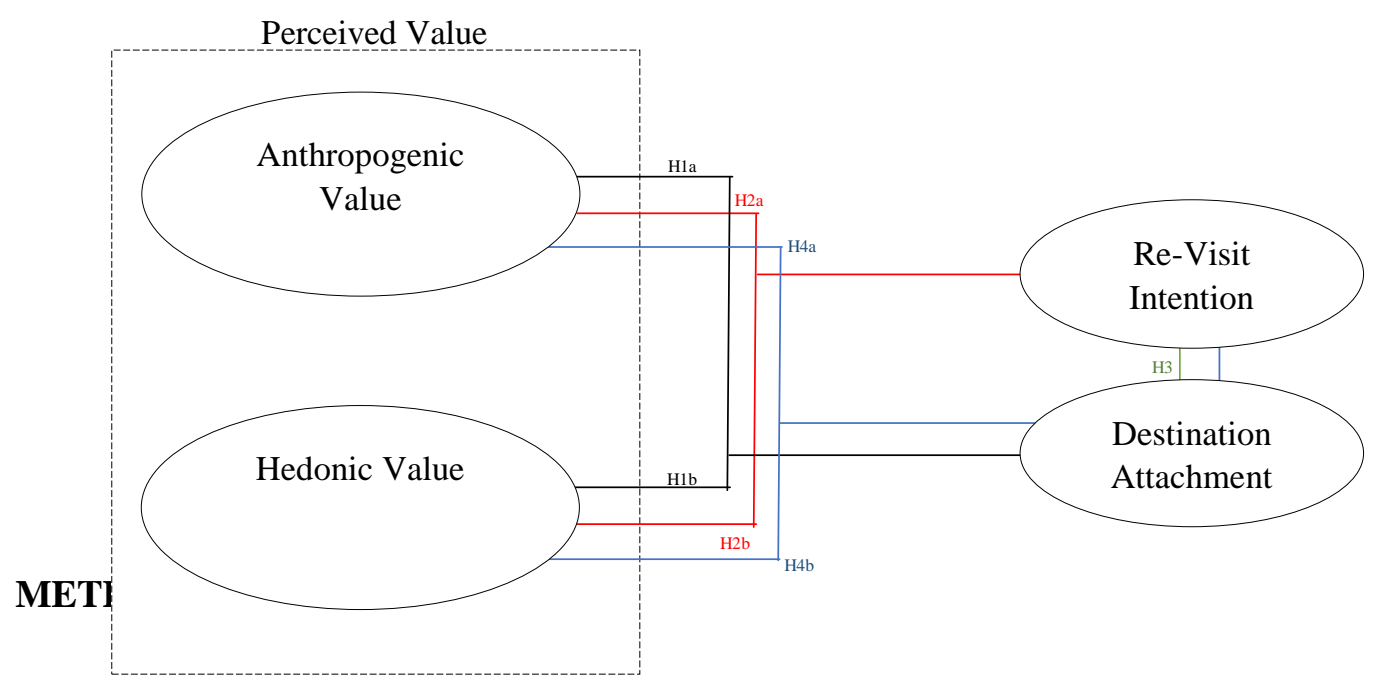

\section{STUDY SITE}

The survey of this study was carried out at 14 community-based tourism destinations in Sarawak, Malaysia as study sites and surveyed 216 tourists visited theses destinations. The sites are the important topical area with a high potential for effective strategic market differentiation for local community-based tourism destinations that still remains unexplored in rural Malaysia. The destinations have been gained popularity among local and international tourists as community-based tourism destinations in the country. The destinations are surrounded by unpopulated natural environment and resources which shared the most common and unique features for tourism activities. These community-based tourism destinations are owned and operated by the local communities. 


\section{SURVEY MEASURES}

The survey was carried out to collect data to be tested the significance of the relationships between the constructs as proposed in the conceptual framework. The survey instrument is developed through using observed variables followed by demographic questions such as gender, age, nationality of the tourists, and visited destination of the tourists. Items used to measure the various constructs under study were derived from existing tourism literature. Perceived value (anthropogenic and hedonic) were adopted from the study of Calver and Page (2013), destination attachment (Yuksel et al., 2010), and re-visit intention was adopted from the study of (Maxham \& Netemeyer, 2002).

\section{SAMPLING PROCEDURES AND DATA COLLECTION}

The judgmental and snowball sampling approaches were applied to meet the aim of this study and respondents were selected purposefully to be confirmed the intended respondents (Newby-Clark, McGregor, \& Zanna, 2002). The study was obtained 226 completed questionnaires where 10 questionnaires were removed due to a large proportion of incomplete responses during the screening process. Finally, 216 usable questionnaires were used for data analysis as the sample size meets the requirements of the minimum sample size to be employed Partial Least Squares-Structural Equation Modeling (PLS-SEM) ${ }^{1}$ (Akter, D'Ambra, \& Ray, 2011; Hair, Hollingsworth, Randolph, \& Chong, 2017; Hoyle, 1995). However, no incentive was offered to the respondents for their participation in this study, it was completely voluntary and prior to their participation an informed consent was obtained.

\section{DATA ANALYSIS TECHNIQUES AND PROCEDURES}

This study used partial least squares SmartPLS-3.0 software as analytical tool and employed structural equation modeling to assess the proposed relationships in the conceptual model under study. The data analysis technique is suitable for exploratory and confirmatory research that aims to investigate the extent to which exogenous or independent latent constructs which predict the endogenous or dependent latent constructs (Hair et al., 2017; Ringle, Wende, \& Becker, 2015).

\footnotetext{
${ }^{1}$ The sample size of cases in the current study meets the required sample sizes of 30 cases (i.e. 10 cases $\times$ maximum of three arrows [i.e. from atmosphere, cultural environment, and destination brand] pointing at a latent research construct [i.e. destination attachment]), 96 cases (i.e. based on power analysis using $\mathrm{G}^{*}$ Power), and 100 to 200 cases for a meaningful structural (or path) analysis, as suggested by Hair et al. (2017), Akter et al. (2011), and Hoyle (1995), respectively.
} 
In PLS-SEM procedures, three steps were used to be assessed the conceptual model of this study. The first step commenced with the test for common method bias using Harman's (1976) single-factor test and collinearity of indicators by computing the variance inflation factor (Hair et al., 2017). The second step strives to establish convergent and discriminant validity in the measurement model by conducting confirmatory factor analysis and correlation analyses. Moreover, factor loadings, composite reliability, average variance extracted (AVE), and Heterotrait-Monotrait (HTMT) were tested against the recommended threshold values (Byrne, 2010; Fornell \& Larcker, 1981; Hair, Anderson, Babin, \& Black, 2010; Henseler, Ringle, \& Sarstedt, 2015; Sarkar, Echambadi, \& Harrison, 2001). Finally, the significance and the effect size of the path relationships in, variance explained by, and predictive relevance of the structural model was examined through using bootstrapping and blindfolding procedures (Hair et al., 2017; Ringle et al., 2015).

\section{FINDINGS}

\section{MANIPULATION CHECKS}

This study performed Common method variance (CMV) using the Harman's (1976) single-factor test for testing the common method bias. In this test, all research constructs are entered into one principal component factor analysis, and thus the extraction method of a principal component of one fixed factor with no rotation is applied (Podsakoff, MacKenzie, Lee, \& Podsakoff, 2003; Podsakoff, MacKenzie, \& Podsakoff, 2012). Results of the factor analysis has shown that the largest variance explained by the first factor was 40.93 percent of the total variance. Moreover, no correlation between research constructs was more than the cut-off point of 0.90 ; the highest correlation between constructs under study was 0.65 (correlation between hedonic value and destination attachment) (Bagozzi, Yi, \& Phillips, 1991). Thus, common method bias was not a concern in this study.

In addition, this study was tested the collinearity of indicators, determined by the Variance Inflation Factor (VIF), was below the critical value of five (Hair et al., 2017). Thus, there is no issue of collinearity of indicators in both the measurement model and structural model of this study. Next, a two-step procedures were employed to be assessed the measurement model of the constructs under study and discriminant validity. Finally, the proposed hypothesizes of the study were tested in structural model (Anderson \& Gerbing, 1988). 


\section{PROFILE OF THE RESPONDENTS}

As mentioned earlier the study investigated tourists who recently visited at different community-based tourism destinations in Sarawak, Malaysia and consists of a total of 216 tourists as respondent for final analysis. Table 1 illustrates that the ratio of female respondents is higher than the male respondents which is 61.6 and 38.4 percent respectively, while in terms of range of age, the dominant respondents are 20 to 29 years of age which is 69.4 percent followed by 30 to 39 years which is 13.0 percent, 40 to 49 years old ( 2.3 percent) and 50 years old and above (1.9 percent). The remaining 13.4 percent are those who are 19 years old and below which constitute mainly students at secondary schools and colleges/ universities. Most of the respondents of this study are Malaysian nationals and a very few are internationals which are 97.2 and 2.8 percent respectively, while the most common destination they visited was Santubong (46.3 percent) and Borneo Height (12.5 percent).

Tab. 1: Destination Visited

\begin{tabular}{llcc}
\hline Variables & Frequency & Percentage (\%) \\
\hline Destination & Kampung Santubong & 100 & 46.3 \\
& Borneo Heights & 27 & 12.5 \\
& Kampung Anas Rais & 16 & 7.4 \\
Kampung Bako & 16 & 7.4 \\
Kampung Tanjung Manis & 16 & 7.4 \\
Gunung Gading Trekking & 13 & 6.0 \\
Trail & & 3.7 \\
Kampung Semadang & 8 & 1.4 \\
Kampung Giam & 3 & 1.4 \\
Kampung Semban & 3 & 0.9 \\
Hot Spring Panchor & 2 & 0.9 \\
Kampung Daro & 2 & 0.9 \\
Damai Beach & 2 & 0.5 \\
Bung Bratak Heritage & 1 & 0.5 \\
Centre & & 0.5 \\
Niah Cave & 1 & 0.5 \\
Kampung Benuk & 1 & 0.5 \\
Kampung Bisira Rayang & 1 & 0.5 \\
Kampung Sabena & 1 & 0.5 \\
Kampung Telian Mukah & 1 & 0.5 \\
\hline Mount Singhai Tracking & 1 & \\
Trail Bau & & \\
Miri Homestay & 1 & \\
\hline
\end{tabular}




\section{ASSESSMENT OF MEASUREMENT MODEL}

In assessing the measurement model, convergent validity was evaluated by examining factor loadings, composite reliability, and Average Variance Extracted (AVE) (Fornell \& Larcker, 1981). As presented in Table 2, standardize factor loadings in the measurement model were above 0.60 , which exceeds the recommended threshold value of 0.60 (Byrne, 2010; Hair et al., 2010). The Composite Reliability (CR) of all constructs under study were above 0.80 , which exceeds the recommended threshold value of 0.70 (Sarkar et al., 2001). Likewise, according to the suggestions of (Fornell \& Larcker, 1981), the AVE values of all research constructs were above the recommended threshold value of 0.50 . Therefore, this study satisfactorily met all the three conditions of convergent validity.

Tab. 2: Confirmatory Factor Analysis Results

\begin{tabular}{|c|c|c|c|c|}
\hline Constructs & Items & $\begin{array}{c}\text { Factor } \\
\text { Loading }\end{array}$ & AVE & $\begin{array}{l}\text { Composite } \\
\text { Reliability }\end{array}$ \\
\hline \multirow[t]{5}{*}{$\begin{array}{l}\text { Anthropogenic } \\
\text { Value }\end{array}$} & ANT1 & 0.734 & 0.572 & 0.869 \\
\hline & ANT2 & 0.803 & & \\
\hline & ANT3 & 0.817 & & \\
\hline & ANT4 & 0.710 & & \\
\hline & ANT5 & 0.710 & & \\
\hline \multirow[t]{7}{*}{ Hedonic Value } & HED1 & 0.751 & 0.519 & 0.883 \\
\hline & HED2 & 0.716 & & \\
\hline & HED3 & 0.737 & & \\
\hline & HED4 & 0.756 & & \\
\hline & HED6 & 0.608 & & \\
\hline & HED7 & 0.764 & & \\
\hline & HED8 & 0.700 & & \\
\hline \multirow{3}{*}{$\begin{array}{l}\text { Destination } \\
\text { Attachment }\end{array}$} & DA1 & 0.937 & 0.822 & 0.933 \\
\hline & DA2 & 0.962 & & \\
\hline & DA3 & 0.934 & & \\
\hline
\end{tabular}


Tab. 2: Confirmatory Factor Analysis Results (Continued)

\begin{tabular}{|c|c|c|c|c|}
\hline Constructs & Items & $\begin{array}{l}\text { Factor } \\
\text { Loading }\end{array}$ & AVE & $\begin{array}{l}\text { Composite } \\
\text { Reliability }\end{array}$ \\
\hline \multirow[t]{3}{*}{ Re-visit Intention } & RI1 & 0.941 & 0.836 & 0.939 \\
\hline & RI2 & 0.908 & & \\
\hline & RI3 & 0.920 & & \\
\hline \multicolumn{5}{|c|}{$\begin{array}{l}\text { a. Average variance extracted }(\mathrm{AVE})=\text { (summation of the square of the factor } \\
\text { loadings }) /([\text { summation of the square of the factor loadings] }+ \text { [summation of } \\
\text { the square of the error variances]) }\end{array}$} \\
\hline \multicolumn{5}{|c|}{$\begin{array}{l}\text { b. Composite Reliability }(\mathrm{CR})=\text { (square of the summation of the factor loadings) } / \\
\text { ([square of the summation of the factor loadings] }+ \text { [square of the summation of } \\
\text { the error variances] })\end{array}$} \\
\hline
\end{tabular}

In assessing the discriminant validity of this study, the criterions recommended by (Fornell \& Larcker, 1981) and Henseler et al.'s (2015) HTMT were used. Fornell and Larcker (1981) suggests that the square root of the AVE should exceed the correlation values between the constructs of the study. As seen in Table 3, the square roots of the AVEs were greater than the correlation values for each research constructs pairing. Discriminant validity of the constructs under study is established based on the suggestions of Henseler et al. (2015) as the threshold value of the HTMT is below 0.90 . Therefore, results of the test of discriminant validity were met.

Tab. 3: Fornell-Larcker and Heterotrait-Monotrait (HTMT) Criterion Results

\begin{tabular}{|c|c|c|c|c|c|c|c|c|}
\hline \multirow[b]{2}{*}{ Variables } & \multicolumn{4}{|c|}{ Fornell-Larcker Criterion* } & \multicolumn{4}{|c|}{$\begin{array}{c}\text { Heterotrait-Monotrait } \\
\text { (HTMT) Criterion }\end{array}$} \\
\hline & $\begin{array}{c}\mathbf{A N} \\
\mathbf{T}\end{array}$ & $\begin{array}{c}\text { HE } \\
\text { D }\end{array}$ & $\begin{array}{l}\mathbf{D} \\
\mathbf{A}\end{array}$ & $\begin{array}{l}\mathbf{R} \\
\mathbf{I}\end{array}$ & $\begin{array}{c}\mathbf{A N} \\
\mathbf{T}\end{array}$ & $\begin{array}{c}\text { HE } \\
\text { D }\end{array}$ & $\begin{array}{l}\mathbf{D} \\
\mathbf{A}\end{array}$ & $\begin{array}{c}\mathbf{R} \\
\mathbf{I}\end{array}$ \\
\hline $\begin{array}{l}\text { Anthropogeni } \\
\text { c Value }\end{array}$ & 0.756 & & & & & & & \\
\hline $\begin{array}{l}\text { Hedonic } \\
\text { Value }\end{array}$ & 0.612 & 0.721 & & & 0.723 & & & \\
\hline $\begin{array}{l}\text { Destination } \\
\text { Attachment }\end{array}$ & 0.423 & 0.658 & 0.907 & & 0.491 & 0.748 & & \\
\hline $\begin{array}{l}\text { Re-visit } \\
\text { Intention }\end{array}$ & 0.533 & 0.512 & 0.472 & $\begin{array}{c}0.91 \\
4 \\
\end{array}$ & 0.620 & 0.583 & 0.526 & \\
\hline
\end{tabular}

*Note: Bold diagonals represent the square root of the AVE while the off-diagonal represent the correlations. 


\section{ASSESSMENT OF STRUCTURAL MODEL}

The structural model of this study was assessed using SmartPLS-3.0 and bootstrapping procedures were used. The analytical technique was utilized to estimate the precision estimates and significance of path relationships between the constructs under study (Hair et al., 2017; Ringle et al., 2015). This was done by generating the T-statistics for significant testing through the bootstrapping procedures. A total of 5,000 cases of sub-samples in bootstrapping procedures were drawn to allow the procedure in estimating the model of each of the sub-samples.

Table 4 depicts the path coefficients findings for the structural model and the results show that hedonic value have significant positive impacts on destination attachment as the t-values of the relationships was 7.224 which met the threshold values. Thus, the hypothesis $\mathrm{H} 1 \mathrm{~b}$ is supported. However, anthropogenic value has significant positive impact on re-visit intention as its t-values was 4.636. Therefore, only the hypothesis $\mathrm{H} 2 \mathrm{a}$ is supported. The findings further indicated that the result of $\mathrm{t}$-value of the relationship of destination attachment on re-visit intention was 3.024, thus H3 is supported. Consequently, it can be concluded that destination attachment has a positive relationship on re-visit intention. Further post hoc (mediation) analysis of the structural model shows that destination attachment mediates the relationship between hedonic value and re-visit intention as its t-value met the threshold value (2.755). Hence, only the hypothesis $\mathrm{H} 4 \mathrm{~b}$ is supported.

In the structural model, the study further assesses the predictive capability or predictive relevance of the structural model through using blindfolding procedures followed by the assessment of the cross-validated redundancy. The study was used Stone-Geisser's predictive relevance $\left(\mathrm{Q}^{2}\right)$ to estimates and co-efficient of determination $\left(\mathrm{R}^{2}\right)$ values to indicates the levels of predictive accuracy of the model (Hair, Hult, Ringle, \& Sarstedt, 2014). As seen in the table 4, the value of $\mathrm{R}^{2}$ for destination attachment and re-visit intention is 0.433 , and 0.368 respectively. The results suggested that anthropogenic and hedonic value explain $43.3 \%$, and $36.8 \%$ of variance in destination attachment, and re-visit intention respectively which is considered as moderate in both the cases. Moreover, the results also show that the $\mathrm{Q}^{2}$ values of destination attachment, and re-visit intention is 0.334 , and 0.287 respectively which suggests that there is a predictive relevance as both the results are larger than 0 . Thus, given the findings of $\mathrm{R}^{2}$ and $\mathrm{Q}^{2}$, it can be concluded that the model has a predictive quality in explaining the relationships between the constructs in structural model. 
Furthermore, based on the suggestions of (Hair et al., 2014), this study assessed the collinearity issue in the inner model through using VIF and effect size $\left(f^{2}\right)$ of the constructs. As the threshold value of VIF $\geq 3.3$ indicates a potential collinearity problem (Diamantopoulos \& Siguaw, 2006), as the results of all the constructs of the structural model are under the threshold value, thus, the result demonstrated that each constructs of the model is distinguished and suitable for structural equation modeling test. Effect size $\left(f^{2}\right)$ is another path coefficient measure. The threshold value of $0.02,0.15$, and 0.35 interpreted as small, medium, and large effect size (Hair et al., 2014). Table 4 shows that hedonic value had a large effect size and significant positive relationship to destination attachment $\left(f^{2}=0.448, \beta=0.642\right)$, but none for anthropogenic value on destination attachment. When hedonic value was tested on re-visit intention, it showed a no effect size and no significant positive relationship. However a medium effect size with significant relationship was observed for anthropogenic value on re-visit intention $\left(f^{2}=0.117, \beta=0.348\right)$. Finally, destination attachment had a medium effect size and significant positive relationship to re-visit intention $\left(f^{2}=0.046, \beta=0.223\right)$ of the study.

Tab. 4: Results of the Structural Model

\begin{tabular}{|c|c|c|c|c|c|c|c|c|}
\hline $\begin{array}{l}\text { Path } \\
\text { Relationship }\end{array}$ & $\begin{array}{c}\text { Beta } \\
(\beta)\end{array}$ & S.E. & t-value & Decision & $f^{2}$ & $\mathbf{R}^{2}$ & VIF & $Q^{2}$ \\
\hline H1a: & 0.03 & 0.09 & 0.368 & Not & 0.00 & 0.43 & 1.59 & 0.33 \\
\hline $\begin{array}{l}\text { Anthropogeni } \\
\text { c Value -> } \\
\text { Destination } \\
\text { Attachment }\end{array}$ & 1 & 1 & & supported & 1 & 3 & 9 & 4 \\
\hline H1b: Hedonic & 0.64 & 0.08 & $7.224 *$ & Supporte & 0.44 & & 1.59 & \\
\hline $\begin{array}{l}\text { Value -> } \\
\text { Destination }\end{array}$ & 2 & 8 & * & d & 8 & & 9 & \\
\hline $\begin{array}{l}\text { Attachment } \\
\text { H2a: }\end{array}$ & 0.34 & 0.07 & $4.636^{*}$ & Supporte & 0.11 & 0.36 & 1.60 & 0.28 \\
\hline $\begin{array}{l}\text { Anthropogeni } \\
\text { c Value -> } \\
\text { Re-Visit } \\
\text { Intention }\end{array}$ & 8 & 4 & * & d & 7 & 8 & 1 & 7 \\
\hline H2b: Hedonic & 0.15 & 0.08 & 1.875 & Not & 0.01 & & 2.31 & \\
\hline $\begin{array}{l}\text { Value -> Re- } \\
\text { Visit Intention }\end{array}$ & 3 & 1 & & supported & 6 & & 5 & \\
\hline H3: & 0.22 & 0.07 & $3.024 *$ & Supporte & 0.04 & & 1.76 & \\
\hline $\begin{array}{l}\text { Destination } \\
\text { Attachment - } \\
>\text { Re-Visit } \\
\text { Intention }\end{array}$ & 3 & 5 & * & d & 6 & & 4 & \\
\hline
\end{tabular}




\begin{tabular}{lcccc}
\hline $\begin{array}{l}\text { Post hoc } \\
\text { (Mediation) }\end{array}$ & & & & \\
Analysis & Beta & S.E. & t-value & Decision \\
\hline H4a: & 0.00 & 0.02 & 0.351 & $\begin{array}{c}\text { Not } \\
\text { supported }\end{array}$ \\
$\begin{array}{l}\text { Anthropogeni } \\
\text { c Value -> }\end{array}$ & 7 & 1 & & \\
Destination & & & & \\
Attachment-> & & & & \\
Re-Visit & & & & \\
Intention & & & & \\
H4b: Hedonic & 0.14 & 0.05 & $2.755^{*}$ & Supporte \\
Value -> & 3 & 2 & $*$ & $\mathrm{~d}$ \\
Destination & & & & \\
Attachment $->$ & & & & \\
Re-Visit & & & & \\
Intention & & & & \\
\hline $\begin{array}{l}\text { Note: VIF }=\text { Variance } \\
\text { Standard errors. }\end{array}$ & & & & \\
\hline
\end{tabular}

\section{DISCUSSIONS}

The general purpose of this study was to determine tourists' destination attachment and re-visit intention towards the community-based tourism destinations in the context of Sarawak, Malaysia as a developing country. The perceived value (anthropogenic and hedonic) of community-based tourism destinations in a developing country are investigated as the antecedents of destination attachment and re-visit intention. The mediating effect of destination attachment was also investigated between the effect of perceived value (anthropogenic and hedonic) and tourists' re-visit intention. The study revealed a mixed finding, with important implications for community-based tourism studies and practices. The importance of perceived value (anthropogenic and hedonic) is on the rise and many researchers have used this construct to explain destination attachment (Nghiêm-Phú, 2018) and re-visit intention (Waheed \& Hassan, 2016). It is noteworthy to explain that tourists' perception of the perceived value (anthropogenic and hedonic) is subjective and it is influenced by many factors (Calver \& Page, 2013). The current study has shown clearly the significant impact of hedonic value on destination attachment. This results are similar with the findings from study conducted by Calver and Page (2013). This study clearly found that the hedonic value has a significant influence on tourists' destination attachment, whereas anthropogenic value has a significant influence on tourists' re-visit intention towards the community-based tourism destinations. 
The current study has also established a strong link between destination attachment of the tourists and their re-visit intention ( $\beta$ destination attachment-revisit intention= 0.223 ) towards community-based tourism destinations. Such finding suggest that an attachment towards community-based tourism destination is a result of the social and cultural environment which it is enticed to (Yuksel et al., 2010). This happen as tourists' who are immersed in cultural tourism (evident for local tourists' who visited local community-based tourism destination) perceive the destination they visited to be cultural attractive and important to them. Such finding suggests to policy makers and practitioners the importance of cultivating and maintaining community-based tourism destination. This study also shown that hedonic value leads to favorable re-visit intention, mediated by destination attachment towards community-based tourism destinations. Such result suggests that destination attachment is important issues to the existing and potential tourists of the community-based tourism destinations as they mainly develop affective and hedonistic aim and value for money with particular community-based tourism destinations, thus having an influence on tourists' favorable re-visit intention. These findings support previous claims that destination attachment can have a role in the development of a national identity in the micro level perspective (Huang et al., 2016; Veasna et al., 2013; Yuksel et al., 2010).

\section{CONCLUSIONS AND IMPLICATIONS}

This study set out to determine the relationship between tourists' perceived value (anthropogenic and hedonic), destination attachment on re-visit intention towards community-based tourism destinations. The current study provides valuable insights of the antecedents of perceived value (anthropogenic and hedonic) and mediating role of destination attachment between perceived value (anthropogenic and hedonic) and re-visit intention. The study presented a comprehensive framework to study perceived value (anthropogenic and hedonic), destination attachment and re-visit intention, mainly from inbound tourism perspective. The effects of the antecedents of perceived value (anthropogenic and hedonic) on destination attachment and revisit intention were further examined using structural equation modeling. The findings indicate a partial effect of all the direct and indirect effects (mediated) tested, thus partial support for the hypotheses listed. The findings provide further discussions on the effect of perceived value (anthropogenic and hedonic) and re-visit intention, as well as the mediating effect of destination attachment towards community-based tourism destinations. 


\section{LIMITATIONS AND SUGGESTIONS FOR FUTURE RESEARCH}

This study is not without its limitations. First, the variety of places and people taken as samples provide a wide diversity to be considered, but the study also did not take into account the different ethnicities. This is particularly important when the target samples are pre-dominantly local tourists' from Malaysia. Malaysia are known for it multi-cultural and multi-ethic society which possess significant impact on how different ethic from different background and culture value particular destinations in relation to the value they inherent/ posses. Second, the samples were also limited to tourists' visiting various community-based tourism destinations in Sarawak, Malaysia. A larger sample covering more community-based tourism destination in other part of Malaysia could provide more robust results. Third, some conceptual problems arise into the notion of destination attachment and re-visit intention. In fact, the Malaysian tourists may have more opportunities to repeatedly visit a particular community-based tourism destination, while it is not often easy for international tourists as various constraints are involved over there such as- visa processing, geographical distance, and financial. Thus, this study suggests to look tourists' perceptions on re-visit intention separately for domestic tourists and international tourists.

The findings also provide a window into the impact of re-visit intention and destination attachment as a dual edged sword, getting new and existing tourist coming back to the tourism destinations they visited. This matter needs to be pursued further. Moreover, the present study considered only two antecedents of perceived value: anthropogenic and hedonic value. Although, the present study tested the structural equation modeling which is an improvement over existing ones, future studies can expand on the model with the inclusion of other antecedents such as personal value, level of involvement, and lifestyle traits of tourists that could have impact on destination attachment and re-visit intention, as well as the mediating effect of destination images. 


\section{REFERENCE LIST}

Akter, S., D'Ambra, J., \& Ray, P. (2011). An evaluation of PLS based complex models: the roles of power analysis, predictive relevance and GoF index. Paper presented at the AMCIS 2011.

Anderson, J. C., \& Gerbing, D. W. (1988). Structural equation modeling in practice: A review and recommended two-step approach. Psychological Bulletin, 103(3), 411-423.

Apostolakis, A., \& Jaffrey, S. (2005). A choice modelling application for Greek heritage attractions. Journal of Travel Research, 43(3), 309-318.

Bagozzi, R. P., Yi, Y., \& Phillips, L. W. (1991). Assessing Construct Validity in Organizational Research. Adminstrative Science Quarterly, 36(3), 421-458.

Bhuiyan, M. A. H., Siwar, C., Ismail, S. M., Islam, R., \& Ehsan, D. (2011). Potentials of Islamic tourism: A case study of Malaysia on east coast economic region. Australian journal of basic and applied sciences, 5(6), 1333-1340.

Byrne, B. M. (2010). Multivariate applications series. Structural equation modeling with AMOS: Basic concepts, applications, and programming (2nd ed.). New York: Routledge/Taylor \& Francis Group.

Calver, S. J., \& Page, S. J. (2013). Enlightened hedonism: Exploring the relationship of service value, visitor knowledge and interest, to visitor enjoyment at heritage attractions. Tourism Management, 39, 23-36.

Chan, J. K. L., \& Baum, T. (2007). Ecotourists' perception of ecotourism experience in lower Kinabatangan, Sabah, Malaysia. Journal of Sustainable Tourism, 15(5), 574-590.

Chen, C. F., \& Chen, F. S. (2010). Experience quality, perceived value, satisfaction and behavioral intentions for heritage tourists. Tourism Management, 31(1), 29-35.

Chin, C. H., \& Lo, M. C. (2017). Rural tourism quality of services: fundamental contributive factors from tourists' perceptions. Asia Pacific Journal of Tourism Research, 22(4), 465-476.

Cochrane, J. (2007). Asian tourism: Growth and change: Routledge.

Cole, S. T., \& Chancellor, H. C. (2009). Examining the festival attributes that impact visitor experience, satisfaction and re-visit intention. Journal of Vacation Marketing, 15(4), 323-333.

Cresswell, T. (2015). Place: An introduction. West Sussex, UK: John Wiley \& Sons. Diamantopoulos, A., \& Siguaw, J. A. (2006). Formative versus reflective indicators in organizational measure development: A comparison and empirical illustration. British Journal of Management, 17(4), 263-282. 
Dodds, R., Ali, A., \& Galaski, K. (2018). Mobilizing knowledge: Determining key elements for success and pitfalls in developing community-based tourism. Current Issues in Tourism, 31(13), 1547-1568.

Fick, G. R., \& Brent Ritchie, J. R. (1991). Measuring service quality in the travel and tourism industry. Journal of Travel Research, 30(2), 2-9.

Fornell, C., \& Larcker, D. F. (1981). Evaluating structural equation models with unobservable variables and measurement error. Journal of Marketing Research, 18(1), 39-50.

Hair, J. J. F., Anderson, R. E., Babin, B. J., \& Black, W. C. (2010). Multivariate data analysis: A global perspective (Vol. 7). Upper Saddle River, NJ: Pearson.

Hair, J. J. F., Hollingsworth, C. L., Randolph, A. B., \& Chong, A. Y. L. (2017). An updated and expanded assessment of PLS-SEM in information systems research. Industrial Management \& Data Systems, 117(3), 442-458.

Hair, J. J. F., Hult, G. T. M., Ringle, C., \& Sarstedt, M. (2014). A primer on partial least squares structural equation modeling (PLS-SEM): Sage Publications.

Harman, H. H. (1976). Modern factor analysis: University of Chicago Press.

Henseler, J., Ringle, C. M., \& Sarstedt, M. (2015). A new criterion for assessing discriminant validity in variance-based structural equation modeling. Journal of the Academy of Marketing Science, 43(1), 115-135.

Holbrook, M. B. (1994). The nature of customer value: an axiology of services in the consumption experience. Service quality: New directions in theory and practice, 21, 21-71.

Holbrook, M. B. (2006). Consumption experience, customer value, and subjective personal introspection: An illustrative photographic essay. Journal of Business Research, 59(6), 714-725.

Hosany, S., Prayag, G., Van Der Veen, R., Huang, S., \& Deesilatham, S. (2017). Mediating effects of place attachment and satisfaction on the relationship between tourists' emotions and intention to recommend. Journal of Travel Research, 56(8), 1079-1093.

Hoyle, R. H. (1995). The structural equation modeling approach: Basic concepts and fundamental issues (R. H. Hoyle ed.). Ca: Sage: Thousand Oaks.

Huang, Y., Qu, H., \& Cao, Y. (2016). Towards an Integrative Model of Destination Attachment: Dimensionality and Influence on Revisit Intention. Tourism Travel and Research Association: Advancing Tourism Research Globally, 11 .

Ibrahim, M. R., \& Shuib, A. (2016). Developing Sustainable Community-Based Tourism Enterprises through Amanah Ikhtiar Malaysia (AIM) in Semporna, Sabah: Opportunities and Challenges. Asia-Pacific Journal of Innovation in Hospitality and Tourism, 5(3), 35-49. 
Iso-Ahola, S. E. (1982). Toward a social psychological theory of tourism motivation: A rejoinder. Annals of Tourism Research, 9(2), 256-262.

Lee, S. Y., Petrick, J. F., \& Crompton, J. (2007). The roles of quality and intermediary constructs in determining festival attendees' behavioral intention. Journal of Travel Research, 45(4), 402-412.

Lepp, A. (2007). Residents' Attitudes towards Tourism in Bigodi Village, Uganda. Tourism Management, 28(3), 876-885.

Lim, E. A. C., \& Ang, S. H. (2008). Hedonic vs. utilitarian consumption: A crosscultural perspective based on cultural conditioning. Journal of Business Research, 61(3), 225-232.

López-Guzmán, T., Sánchez-Cañizares, S., \& Pavón, V. (2011). Community-based tourism in developing countries: a case study. Tourismos, 6(1), 69-84.

Ly, T. P., \& Bauer, T. (2017). Ecotourism in Thailand, Cambodia, and Vietnam: Theory and Practice. International Leisure Review, 6(1), 19-31.

Manyara, G., \& Jones, E. (2007). Community-based tourism enterprises development in Kenya: An exploration of their potential as avenues of poverty reduction. Journal of Sustainable Tourism, 15(6), 628-644.

Martín-Ruiz, D., Castellanos-Verdugo, M., \& de los Ángeles Oviedo-García, M. (2010). A visitors' evaluation index for a visit to an archaeological site. Tourism Management, 31(5), 590-596.

Maxham, J. G., \& Netemeyer, R. G. (2002). A longitudinal study of complaining customers' evaluations of multiple service failures and recovery efforts. Journal of Marketing, 66(4), 57-71.

Newby-Clark, I. R., McGregor, I., \& Zanna, M. P. (2002). Thinking and caring about cognitive inconsistency: When and for whom does attitudinal ambivalence feel uncomfortable? Journal of Personality and Social Psychology, 8(2), 157-166.

Nghiêm-Phú, B. (2018). Correlation between tourists' perceptions/evaluations of destination attributes and their overall satisfactions: Observations of a metaanalysis. European Journal of Tourism Research, 19, 98-115.

Otto, J. E., \& Ritchie, J. B. (1996). The service experience in tourism. Tourism Management, 17(3), 165-174.

Podsakoff, P. M., MacKenzie, S. B., Lee, J. Y., \& Podsakoff, N. P. (2003). Common method biases in behavioral research: a critical review of the literature and recommended remedies. Journal of Applied Psychology, 88(5), 879-903.

Podsakoff, P. M., MacKenzie, S. B., \& Podsakoff, N. P. (2012). Sources of Method Bias in Social Science Research and Recommendations on How to Control it. Annual Review of Psychology, 65, 539-569.

Porter, M. E. (1990). The competitve advantage of nations. New York: The Free Press. 
Promsivapallop, P., \& Kannaovakun, P. (2017). A comparative assessment of destination image, travel risk perceptions and travel intention by young travellers across three ASEAN countries: a study of German students. Asia Pacific Journal of Tourism Research, 22(6), 634-650.

Ramkissoon, H., Uysal, M., \& Brown, K. (2011). Relationship between destination image and behavioral intentions of tourists to consume cultural attractions. Journal of Hospitality Marketing \& Management, 20(5), 575-595.

Ringle, C. M., Wende, S., \& Becker, J. M. (2015). SmartPLS 3. Boenningstedt: SmartPLS GmbH. from http://www. smartpls. com.

Russell, P. (2000). Community-based tourism. Travel and Tourism Analyst(5), 89116.

Ryu, K., Han, H., \& Jang, S. (2010). Relationships among hedonic and utilitarian values, satisfaction and behavioral intentions in the fast-casual restaurant industry. International Journal of Contemporary Hospitality Management, 22(3), 416-432.

Salazar, N. B. (2012). Tourism imaginaries: A conceptual approach. Annals of Tourism Research, 39(2), 863-882.

Sarkar, M. B., Echambadi, R. A. J., \& Harrison, J. S. (2001). Alliance entrepreneurship and firm market performance. Strategic management journal, 22(6-7), 701-711.

Song, H. M., Kim, K. S., \& Yim, B. H. (2017). The Mediating Effect of Place Attachment on the Relationship between Golf Tourism Destination Image and Revisit Intention. Asia Pacific Journal of Tourism Research, 22(11), 1182-1193.

Stylos, N., Bellou, V., Andronikidis, A., \& Vassiliadis, C. A. (2017). Linking the Dots among Destination Images, Place Attachment, and Revisit Intentions: A Study among British and Russian Tourists. Tourism Management, 60, 1529.

Suntikul, W., \& Jachna, T. (2016). The co-creation/place attachment nexus. Tourism Management, 52, 276-286.

Taylor, R., \& Shanka, T. (2008). Cause for event: not-for-profit marketing through participant sports events. Journal of Marketing Management, 24(9-10), 945958.

UNWTO. (2014). UNWTO/GTERC Annual Report on Asia Tourism Trends: UNWTO.

Veasna, S., Wu, W. Y., \& Huang, C. H. (2013). The impact of destination source credibility on destination satisfaction: The mediating effects of destination attachment and destination image. Tourism Management, 36(June), 511526. 
Waheed, N., \& Hassan, Z. (2016). Influence of customer perceived value on tourist satisfaction and revisit intention: A study on guesthouses in Maldives. International Journal of Accounting, Business and Management, 4(1), 101123.

Wickham, T. D. (2000). Attachment to places and activities: the relationship of psychological constructs to customer satisfaction. The Pennsylvania State University.

Winter, T. (2007). Rethinking tourism in Asia. Annals of Tourism Research, 34(1), 27-44.

Yuksel, A., Yuksel, F., \& Bilim, Y. (2010). Destination attachment: Effects on customer satisfaction and cognitive, affective and conative loyalty. Tourism Management, 31(2), 274-284.

Zeithaml, V. A. (1988). Consumer perceptions of price, quality, and value: a meansend model and synthesis of evidence. The Journal of Marketing, 52(3), 222.

Zeppel, H. (2006). Indigenous ecotourism: Sustainable development and management (Vol. 3): Cabi.

Zhang, H., Fu, X., Cai, L. A., \& Lu, L. (2014). Destination Image and Tourist Loyalty: A Meta-analysis. Tourism Management, 40, 213-223. 